\title{
Chronological Overview of Management of Raw Minerals in Varazdin County
}

\author{
Melita SRPAK*, Silvija ZEMAN, Željko KNOK
}

\begin{abstract}
Mining is the branch of the economy which is most represented in the Varaždin County. The usable value of mineral raw materials is constantly changing, depending on the needs, and it is the job of the profession to continually assess its value. Mineral raw materials are usually defined as natural aggregates of minerals and/or natural compounds that can be used for different economic needs and are primarily considered from the point of view of the possibility of being put into function or through possible exploitation. The aim of this paper is to present the actual situation in the area related to the exploration and exploitation of mineral resources in the period from the preparation of the first Study of the potential and basis of mineral resources management in the Varaždin County to the present day through the analysis of the current spatial plans of cities and municipalities.
\end{abstract}

Key words: area of research; exploitation fields; mineral raw materials; Varaždin county

\section{INTRODUCTION}

Mining is one of the oldest branches of the economy engaged in the exploration and exploitation of mineral resources. Ores are a national treasure representing a natural resource of interest to the Republic of Croatia under its special protection and can be used exclusively under the conditions and in the manner prescribed by the Mining Act [1] and by-laws. Mineral raw materials (ores) in the Varaždin County are obtained (mined, extracted and exploited) by surface, underground, underwater ways, and are refined (processed) by various methods at mining facilities [2].

Mineral resources (ores) of the Republic of Croatia, including the Varaždin County, enable the exploitation and processing of mineral resources in the oil, chemical, glass, ceramic, cement, refractory, brick and architectural and building stone industries, and in particular in the construction industry [3]. The possibilities, that is, restrictions on the exploitation of mineral resources depend on geological, genetic, technical-exploitation, regional, market and socio-economic factors. Any agglomeration of rocks is considered as a reservoir of mineral raw material only if it is determined that there is the technology to extract minerals or energy from it, to have it in sufficient quantities for economical exploitation, and that the reservoir conditions are economical, i.e. enable the exploitation of mineral resources [4].

However, intensive industrial development, with the increasing needs for exploitation of mineral resources, especially energy, has recently caused a number of environmental problems (climate change, ozone depletion, droughts, forest destruction, threats to the conservation of biological species and others). Addressing these issues imposes a whole new approach in all industries, including mining, which involves the direct inclusion of environmental protection and conservation in development plans [5].

Therefore, the future use of the area related to the exploration and exploitation of mineral resources will be determined by the State Spatial Development Plan of the Republic of Croatia (currently being prepared), and in the process of its preparation it is proposed to rationally identify the areas in which day-to-day development of these activities is possible, respecting environmental laws and regulations.

\section{PLANNING DOCUMENTS FOR MINERAL RESOURCES MANAGEMENT IN THE VARAŽDIN COUNTY}

The Mineral Resources Management Strategy of the Republic of Croatia is the basic document that defines the management of mineral resources and plans the mining activities at the state level [6].

According to the Mining Act, the counties are obliged to prepare mining-geological studies for their areas that cover the existing and potential mineral deposits and which must be in accordance with the Strategy, and submit them to the ministries responsible for mining, spatial planning and nature and environment protection.

A new Mining and Geological Study of the Varaždin County (June 2016) is the starting point for activities in the planning and approval of exploration and exploitation of mineral resources in the County, rehabilitation of abandoned and closed mines [7]. In accordance with the applicable regulations in the field of spatial planning, planning of exploration areas and mineral exploitation fields will be the topic of spatial development, which will be covered by the future Spatial Development Plan of the Republic of Croatia.

Until the adoption of the National Spatial Development Plan of the Republic of Croatia, the Mining and Geological Survey of the Varaždin County shall be used in the procedures of drawing up the spatial plans and their amendments and supplements at the County level. In all these procedures, the Study's recommendations and guidelines are respected in such a way that the requirements for the exploration and exploitation of mineral resources are aligned with the requirements of environmental protection [8], nature and cultural and historical heritage, with the highest priority being the protection of drinking water beds [9].

Determining the locations for future exploration and exploitation of mineral resources cannot be ensured everywhere in the area, as there are prohibitions, restrictions and special conditions that affect the selection of potential sites and their size. Priorities in selection are given in the areas of higher geological potentiality, although the data indicating geological potentiality in 
convenience zones determined by distances from construction sites, infrastructure and other spatial features should be taken into account. Therefore, the provisions for the implementation of spatial plans define the conditions of space limitations according to their use and purpose. Pursuant to the Physical Planning Act [10], spatial plans have the force and legal nature of the by-law.

Spatial plans treat the exploitation of mineral resources as a transitional period (irrespective of the long-term exploitation) and in these documents, as a rule, the final use of space according to the Rulebook on content, map scales, mandatory spatial indicators and compulsory attachments to spatial plans is determined [11]. Mostly, these are sports and recreational purposes in the areas of exploitation of gravel and sand, economic purposes - production zones in the areas of exploitation of stone, clay, etc., possibly tourism purposes, etc., and where it is not realistic or purposeful the recultivation or natural succession is defined [12].

Management of natural resources in accordance with the concept of sustainable development - geological information provides an estimate of the quantities and availability of renewable natural resources and enables their exploitation in an economically cost-effective way that is environmentally friendly [20].

\section{ANALYSIS OF THE SITUATION IN THE MINERAL RESOURCES MANAGEMENT IN THE PERIOD FROM 2006 TO 2010 IN THE AREA OF THE VARAŽDIN COUNTY}

Due to the great interest in the exploitation of mineral resources in the Varaždin County, especially gravel and sand, the County has developed and adopted the Study on the potential and basis of mineral resources management in the Varaždin County. The County Assembly accepted the Study and in such a way the County determined itself with respect to resolving the request for mineral exploration and ensuring the conditions for it through the spatial planning documentation. A particularly significant result of the Study was the mapping: "Limited potentialities of mineral resources in the Varaždin County", [13]. These areas of limited potential were appropriately incorporated into the spatial plans of municipalities and cities as they were amended (Fig. 1).

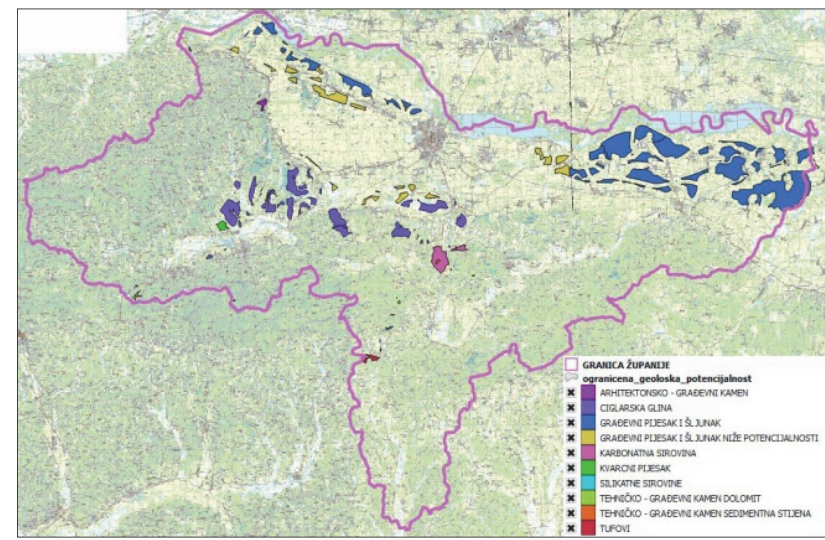

Figure 1 Limited potentialities of mineral resources in the Varaždin County

In the Varaždin County, during those years, mineral raw materials with exclusive use in construction were exploited: exploitation and processing of technical building stone (Tab. 1), construction sand and gravel (Tab. 2), brick clay (Tab. 3) and other (Tab. 4). The use of mineral resources depended on the needs of the market, and production depended on the natural potential.

Table 1 Exploitation fields and exploration areas of technical building stone

\begin{tabular}{|c|c|c|c|c|c|}
\hline No. & Exploitation field & Area in ha & JLS & Date of decision & Investor \\
\hline 1. & Hruškovec (diabase) & 54.29 & Municipality Ljubešćica [28] & $1975(1989)$ & Kaming d.d. Ljubešćica \\
\hline 2. & Pećina (vinicit) & 0.18 & Municipality Vinica [37] & $08 / 06 / 1977$ & Jedinstvo - Kamen d.o.o. \\
\hline 3. & Očura (dolomite) & 20.3 & Town Lepoglava [22] & $12 / 06 / 1985$ & IGM Kamenolom Očura \\
\hline 4. & Belski dol (limestone) & 3.9 & Town N. Marof [18] & $19 / 07 / 1987$ & Vodogradnja d.d. \\
\hline 5. & Jazvina - Hruškovec IV & 15.7 & Municipality Ljubešcica [28] & $05 / 08 / 1988$ & Kaming d.d. Ljubešćica \\
\hline 6. & Špica (limestone) & 46.8 & Municipality Ljubešćica [28] & $09 / 01 / 1993$ & Kaming d.d. Ljubešćica \\
\hline 7. & Podevčevo (dolomite) & 6.1 & Town N. Marof [18] & $10 / 05 / 1995$ & Vlado Puškadija,Remet \\
\hline 8. & Marčan (tor. limestone) & 2.23 & Municipality Vinica [37] & $30 / 10 / 1995$ & Zagorje - Kamen d.o.o. \\
\hline 9. & Čanjevo (limestone breccia) & 6.9 & Municipality Visoko [19] & $05 / 03 / 1998$ & Cesta - Varaždin d.d. \\
\hline 10. & Očura II (dolomite) & 17.2 & Town Lepoglava [22] & $10 / 05 / 2000$ & IGM Kamenolom Očura \\
\hline 11. & Crlena zemlja (diabase) & 1.3 & Municipality B. Hum [25] & $13 / 12 / 2004$ & Raport d.o.o. Radešić \\
\hline 12. & Žulinec & & Municipality Ljubešćica [28] & Prema PPUO Ljubešćica \\
\hline 13. & Belski dol Gornji & 7.6 & Town N. Marof [18] & $05 / 10 / 199 x$ & GTP Sudovec d.o.o. \\
\hline 14. & Očura III & 11.23 & Town Lepoglava [22] & $11 / 06 / 2008$ & Holcim d.o.o. \\
\hline
\end{tabular}

Table 2 Exploitation fields and exploration areas of building sand and gravel

\begin{tabular}{|c|c|c|c|c|c|}
\hline No. & Exploitation field & Area in ha & JLS & Date of decision & Investor \\
\hline 1. & Motičnjak & 55.5 & Municipality T. Bartolovečki [35] & $15 / 11 / 1978$ & Cesta - Mineral d.o.o., Varaždin \\
\hline 2. & Trstika & 32.9 & Municipality Veliki Bukovec & $27 / 10 / 2000$ & Obrt Smontara,Veliki Bukovec \\
\hline 3. & Jamičak & 42.9 & Municipality Sveti Đurđ [34] & $27 / 03 / 2001$ & Obrt Bagerkop - Rauš, N. Marof \\
\hline 4. & Turnišće & 10.5 & Municipality Sračinec [33] & $12 / 12 / 2001$ & Meteor grupa \\
\hline 5. & Hrastovljan & 47.9 & Municipality D. Martijanec [30] & $03 / 09 / 2002$ & Cesta - Mineral d.o.o., Varaždin \\
\hline 6. & Lešce & 19.8 & Municipality Sveti Đurđ [34] & $10 / 02 / 2003$ & Cesta - Mineral d.o.o., Varaždin \\
\hline 7. & Prudnica & 14.9 & Municipality Mali Bukovec [29] & $19 / 07 / 2004$ & Obrt Josip Šrbetar, M. Bukovec \\
\hline 8. & Molve & 24.0 & Municipality Petrijanec [32] & $04 / 02 / 2005$ & Obrt Niskogradnja Huđek Petrij. \\
\hline 9. & Krtinje & 18.2 & Municipality Mali Bukovec [29] & $21 / 12 / 2004$ & Balija d.o.o. N. Selo Podravsko \\
\hline No. & Exploration area & Area in ha & JLS & Date of decision & Investor \\
\hline 10. & Škareški lug & 15.9 & Municipality Veliki Bukovec [36] & $06 / 06 / 2005$ & Obrt Transporti Lilek, Kapela P. \\
\hline 11. & Brezine & 5.9 & Municipality Cestica [26] & $27 / 06 / 2005$ & Cesta - Mineral d.o.o. \\
\hline
\end{tabular}


Table 3 Exploitation fields and exploration area of brick clay

\begin{tabular}{|c|c|c|c|c|c|}
\hline No. & Exploitation field & Area in ha & JLS & Date of decision & Investor \\
\hline 1. & Čret & 27.1 & Town Lepoglava [22] & $24 / 01 / 1980$ & IGM Lepoglava \\
\hline 2. & Cerje Tužno & 54.4 & Municipality Maruševec [31] & $04 / 05 / 1981$ & IGM Brickyard Cerje Tužno \\
\hline 3. & Cukavec & 13.2 & Municipality G. Kneginec [27] & $25 / 08 / 1988$ & Brickyard Dubravka d.o.o. \\
\hline 5. & Lukavec & 32.8 & Town Ivanec [21] & $28 / 02 / 2002$ & IGM Brickyard Cerje Tužno \\
\hline 6. & Cukavec II & 7.4 & Municipality G. Kneginec [27] & $17 / 03 / 2005$ & Brickyard Dubravka d.o.o. \\
\hline 7. & Ludbreški vinogradi & & & & Prema PPUG Ludbrega \\
\hline No. & Exploitation area & Area in ha & JLS & Date of decision & Investor \\
\hline 8. & Cerje Tužno II & & Municipality Maruševec [31] & & IGM Brickyard Cerje Tužno \\
\hline
\end{tabular}

Table 4 Exploitation fields of quartz sand and geothermal wells

\begin{tabular}{|c|c|c|c|c|}
\hline No. & Exploitation field & Area in ha & JLS & Investor / Concessionaire \\
\hline 1. & Jerovec & 21.1 & Town Ivanec [21] & IGM Pješčara Jerovec 17.11.1975. \\
\hline 2. & Varaždinske Toplice & & Town V. Toplice [24] & $\begin{array}{c}\text { Special Hospital for Medical Rehabilitation Varaždinske } \\
\text { Toplice }\end{array}$ \\
\hline 3. & Lunjkovec & & Municipality Mali Bukovec [29] & INA d.d. Zagreb \\
\hline 4. & Topličica & & Town Novi Marof [18] & \\
\hline
\end{tabular}

The study of the potential and basis of mineral resources management in the Varaždin County also indicates the existence of geothermal water sources in Podvčevo (town of Novi Marof) on the east side of Remetinec - Podevčevo road, but there is no data to indicate significant exploration and use of geothermal water from these sources [13 ].

According to the data of the Ministry of Labour and Entrepreneurship of the Republic of Croatia for 2006, the Mining Directorate, in the territory of the Varaždin County, the potential area for the exploitation of mineral resources is about $65 \mathrm{~km}^{2}$, or $5 \%$ of the total area of the County (of which $47.2 \mathrm{~km}^{2}$ is suitable for exploitation of sand and gravel, and $13 \mathrm{~km}^{2}$ for the exploitation of brick clay).

Generally, the County Spatial Plan defines the procedure for exploration and exploitation of mineral resources, which means that only the locations of significance for the County were entered into the graphic part of the plan at the time of the development of the Spatial Plan of the Varaždin County, while the implementing provisions enabled the formation and opening of newly created exploitation fields under certain conditions [12].

In order to harmonize the management of mineral resources with environmental and nature protection conditions [16], natural heritage, agricultural land, as well as with new regulations on mining, the Varaždin County has initiated the initiative to revise/develop a new Study on the potential and basics of mineral resources management in the area of the Varaždin County.

\section{STATE OF EXPLORATION AND EXPLOITATION OF MINERAL RESOURCES IN THE VARAŽDIN COUNTY}

According to the Mining Act [1], data on existing exploitation fields and exploration areas were kept in the Register of approved exploration areas and the Register of identified exploitation fields of mineral resources, in the State Administration Offices in counties (for mineral raw materials for the production of building materials: technical-building stone, construction sand and gravel and brick clay) while the Ministry is responsible for energy mineral raw materials, mineral raw materials for industrial processing, architectural stone and metal mineral raw materials.

At the end of 2017, under the Mining Act, the Ministry of Economy, Entrepreneurship and Crafts took over from the State Administration Office all competencies related to the management of mineral resources in the existing exploration areas and exploitation fields.

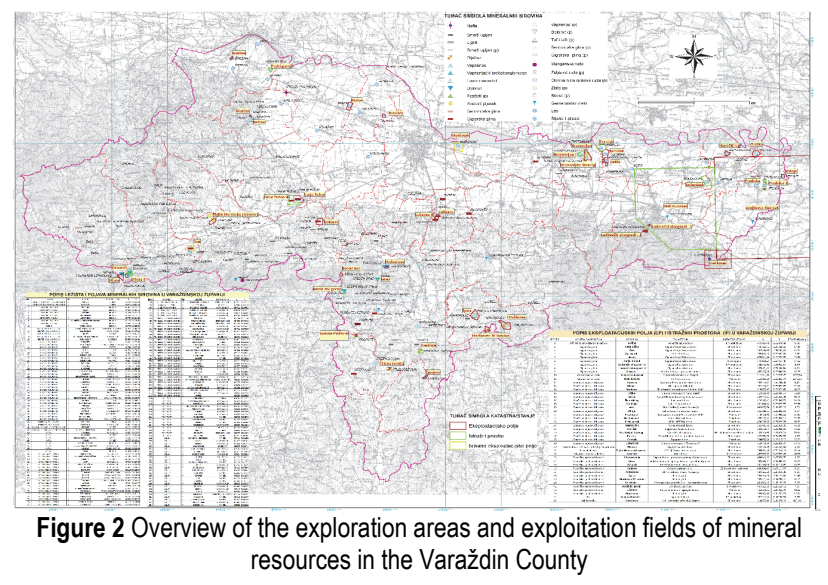

Up to 2017, the registers kept by the State Administration Office in the Varaždin County recorded a total of 17 active exploitation fields (7 technicalconstruction stone, 7 construction sand and gravel and 3 brick clay), as well as 5 exploration areas of construction gravel, and sand [17]. For some of the exploitation fields and exploration areas, the licensees have been deprived of the right of exploitation/exploration of mineral resources, and the competent authority considers such fields passive (Fig. 2).

According to the data of the Institute for Physical Planning of the Varaždin County (based on the data obtained from the State Administration Office in the Varaždin County, the Department of Economy and data of the Ministry of Economy, Energy and Mining Directorate), mineral resources are being explored and exploited in the County within the following exploration areas (IP), that is, exploitation fields (EP), as described below by types of mineral resources.

\subsection{Technical Building Stone}

According to the Register of Exploitation Fields kept by the State Administration Office in the Varaždin County, the Department of Economy until 2017 operated the following exploitation fields of technical building stone: 
According to the data in Tab. 5, the total area (maximum) of all exploitation fields of technical construction stone in the area of the Varaždin County is $162,815 \mathrm{ha}$, and the total area of active exploitation fields is 126,745 ha [17].

In the area of the Varaždin County (City of Lepoglava) there is a very small part of the exploitation field "Lovno Lovno 2" (0.49 ha), on which the technical-building dolomite stone is exploited, and which is mostly located in the area of the Krapina-Zagorje County, in the Municipality of Novi Golubovec (total area of 31.00 ha) [17].

Limestone and dolomitized limestone were exploited in Belski dol, and because of the wells and established water protection zones, this exploitation ceased. With the PPUG of Novi Marof, this exploitation field is no longer planned, that is, the existing field that is within the sanitary zones of Belski dol well protection is planned to be closed and rehabilitated [18].

Until 2003 the exploitation field of the technicalbuilding stone - limestone breccia "Canjevo" in the municipality of Visoko was also in operation, but the exploitation was suspended on the basis of the decision of the Ministry of Economy in 2003 and the ruling of the Administrative Court of 2007 and at the initiative of the Ministry of Culture for the Protection of the cultural property of the Čanjevo Fort [19].

Table 5 Technical - building stone

\begin{tabular}{|c|c|c|c|c|c|}
\hline \\
\hline No. & Exploitation field & Mineral raw material & Area / ha & JLS & Authorised person \\
\hline 1. & Očura & Technical - building stone - dolomite & 20.34 & Town Lepoglava [22] & $\begin{array}{c}\text { IGM Quarry Očura d.o.o. } \\
\text { Lepoglava }\end{array}$ \\
\hline 2. & Očura II & Technical - building stone - dolomite & 17.23 & Town Lepoglava [22] & $\begin{array}{l}\text { Holcim mineralni agregati d.o.o. } \\
\text { Očura }\end{array}$ \\
\hline 3. & Hruškovec & Technical - building stone - diabase & 54.29 & Municipality Ljubešćica [28] & Kaming d.d. Ljubešćica \\
\hline 4. & Hruškovec IV-Jazvina & Technical - building stone - diabase & 15.7 & Municipality Ljubešćica [28] & Kaming d.d. Ljubešćica \\
\hline 5. & Belski dol & Technical - building stone - limestone & 6.06 & Town Novi Marof [18] & Vodogradnja d.d. Varaždin \\
\hline 6. & Špica & Technical - building stone - limestone & 46.0 & Municipality Ljubešćca [28] & Kaming d.d. Ljubešćica \\
\hline 7. & Podevčevo & Technical - building stone - dolomite & 6.3 & Town Novi Marof [18] & $\begin{array}{l}\text { "Graditelj" Vlado Puškadija, } \\
\text { Novi Marof }\end{array}$ \\
\hline 8. & Črlena zemlja & Technical - building stone - diabase & 1.22 & $\begin{array}{c}\text { Municipality Breznički Hum } \\
{[25]}\end{array}$ & Mežnar d.o.o. Karlovac \\
\hline No. & Exploration area & Mineral raw material & Area / ha & JLS & Authorised person \\
\hline 1. & Očura III & Technical - building stone & 11.23 & Town Lepoglava [22] & Holcim mineralni agregati d.o.o. \\
\hline
\end{tabular}

\subsection{Building Sand and Gravel}

There are significant amounts of building sand and gravel in the Varaždin County area associated with the Drava River alluvium. The thickness of the gravelly-sandy horizon increases from west to east, and at Otok Virje it is
$8 \mathrm{~m}$, at Varaždin it is $60 \mathrm{~m}$, and at Hrastovljan it is over 100 $\mathrm{m}$ [12]. Approved exploitation fields, according to the Register of exploitation fields kept by the State Administration Office in the Varaždin County, the Department of Economy until 2017 were as follows.

Table 6 Building sand and gravel

\begin{tabular}{|c|c|c|c|c|c|}
\hline No. & Exploitation field & Mineral raw material & Area / ha & JLS & Authorised person \\
\hline 1. & Trstika & Building sand and gravel & 32.9 & Municipality Veliki Bukovec & Gravel pit transport "Smontara" Veliki Bukovec \\
\hline 2. & Jamičak & Building sand and gravel & 42.9 & Municipality Sveti Đurđ [34] & Bagerkop-Roberto d.o.o. Novi Marof \\
\hline 3. & Turnišće & Building sand and gravel & 8,61 & Municipality Sračinec [33] & Gravel pit Turnišće d.o.o Varaždin \\
\hline 4. & Škareški lug & Building sand and gravel & 16,0 & Municipality Veliki Bukovec & LTK d.o.o. Kapela Podravska \\
\hline 5. & Hrastovljan & Building sand and gravel & 46.4 & Municipality Martijanec [30] & Colas Mineral d.o.o. Varaždin \\
\hline 6. & Lešće & Building sand and gravel & 19.78 & Municipality Sveti Đurđ [34] & Cesta-Mineral d.o.o. Varaždin \\
\hline 7. & Prudnica & Building sand and gravel & 14,99 & Municipality Mali Bukovec [29] & Bukovec \\
\hline 8. & Molve & Building sand and gravel & 24.0 & Municipality Petrijanec [32] & Obrt Niskogradnja Huđek Petrijanec \\
\hline 9. & Krtinje & Building sand and gravel & 9.5 & Municipality Mali Bukovec [29] & Balija d.o.o. Novo Selo Podravsko \\
\hline 10. & Brezine & Building sand and gravel & 4.5 & Municipality Veliki Bukovec & Cesta Mineral d.o.o. Varaždin \\
\hline No. & Exploration area & Mineral raw material & Area (ha) & & Authorised person \\
\hline 1. & Prundica 2 & Building sand and gravel & 8.3 & Municipality Mali Bukovec [29] & Gravel pit and transportation "JOLE" Mali \\
\hline 2. & Černjak & Building sand and gravel & 38.3278 & Municipality Sveti Đurđ [34] & Trgograd d.o.o. Varaždin \\
\hline 3. & Dolenščak & Building sand and gravel & 50.4 & Municipality Sveti Đurđ [34] & V. Bukovec \\
\hline 4. & Peski gornji & Building sand and gravel & 10.4 & Municipality Cestica [26] & Sirik Beton j.d.o.o. Gornje Vratno \\
\hline 5. & Hrastovljan I & Building sand and gravel & 23.56 & Municipality Martijanec [30] & Colas Mineral d.o.o. Varaždin \\
\hline
\end{tabular}

According to the data in Tab. 6, it is evident that the total (maximum) area of all exploitation fields of building sand and gravel in the area of the Varaždin County is $221.02 \mathrm{ha}$, and the total area of active exploitation fields is $187.16 \mathrm{ha}$. The total area of exploration areas of this mineral resource in the County is 130.9878 ha [17].

Until 2013 the exploitation field of building sand and gravel "Motičnjak" in the municipality of Trnovec
Bartolovečki was also in operation, at which the exploitation was completed and it was deleted from the Register of exploitation fields [35].

\subsection{Brick Clay}

Brick clay is exploited at several locations in the Varaždin County, where there are certain capacities and 
potentials, but the quality of the raw material varies and the quantities are limited.

It is estimated that only the brick mill in Cerje Tužno has sufficient raw materials for longer exploitation. According to the Register of Exploitation Fields kept by the State Administration Office in the Varaždin County, the Department of Economy until 2017 the following brick clay exploitation fields were in operation.
Exploitation fields of brick clay in the area of the Varaždin County is 116.46 ha, and the total area of active exploitation fields is 70.65 ha [17].

The Ludbreg PPUG established that no further exploitation was carried out on the exploitation field next to the existing brickyard (EP Ludbreški Vinogradi - north), and it was no longer planned as an exploitation field but a construction area of the settlement [23].

Table 7 Brick clay

\begin{tabular}{|c|c|c|c|c|c|}
\hline No. & Exploitation field & Mineral raw material & Area / ha & JLS & Authorised person \\
\hline 1. & Cerje Tužno & Brick clay & 54.5 & Municipality Maruševec [31] & $\begin{array}{c}\text { Brickyard Cerje Tužno d.o.o. Cerje } \\
\text { Nebojse }\end{array}$ \\
\hline 3. & Cukavec & Brick clay & 12.96 & Municipality Gornji Kneginec [27] & Leier-Leitl d.o.o., Turčin \\
\hline 4. & Cukavec II & Brick clay & 7.4 & Municipality Gornji Kneginec [27] & Leier-Leitl d.o.o., Turčin \\
\hline 5. & Lukavec & Brick clay & 32.85 & Town Ivanec [21] & $\begin{array}{c}\text { IGM Brickyard Cerje Tužno d.o.o. } \\
\text { Lepoglava }\end{array}$ \\
\hline 6. & Ludbreški Vinogradi - north & Brick clay & 1.95 & Town Ludbreg [23] & Brickyard Kovačić d.o.o. Ludbreg \\
\hline 7. & Ludbreški Vinogradi - south & Brick clay & 6.8 & Town Ludbreg [23] & Brickyard Kovačić d.o.o. Ludbreg \\
\hline
\end{tabular}

\subsection{Geothermal Water}

Until 2012 the exploitation field of the Čret brick clay in the town of Lepoglava was also in operation, at which the exploitation was completed and it was deleted from the Register of exploitation fields [22]. In the Varaždin
County, energy mineral resources (hydrocarbons/oil and fossil fuels/geothermal water) and mineral resources for industrial processing (sand) under the jurisdiction of the Ministry of Economy are also explored and exploited (Tab. 8).

Table 8 Geothermal water

\begin{tabular}{|c|c|c|c|c|c|}
\hline No. & Exploitation field & Mineral raw material & Area / ha & JLS & Authorised person \\
\hline 1. & Varaždinske Toplice & Thermomineral water & - point source - well & Town Varaždinske Toplice [24] & 1 \\
\hline 2. & Lunjkovec-Kutnjak & Geothermal water & $10.000,00$ & Municipality Mali Bukovec [29] & MB GEOTHERMAL d.o.o. Zagreb \\
\hline 3. & Topličica & Geothermal water & - point source & Town Novi Marof [18] & / \\
\hline No. & Exploration area & Mineral raw material & Area / ha & JLS & Authorised person \\
\hline 1. & Mali Bukovec & Geothermal water & $5.248 .00 *$ & Municipality Mali Bukovec [29] & Vis Viridis d.o.o. Zagreb \\
\hline
\end{tabular}

\subsection{Sand}

exploited under the jurisdiction of the Ministry of

In the Varaždin County, mineral resources for industrial processing (quartz sand) are explored and

Economy. In the Varaždin County there is only one active field of mineral raw material - quartz sand (Tab. 9).

\begin{tabular}{|c|c|c|c|c|c|c|}
\hline \multicolumn{9}{|c|}{ Table 9 Sand } \\
\hline No. & Exploitation field & Mineral raw material & Area / ha & JLS & Date of decision & Authorised person \\
\hline 1. & Tiglin - Horvacka (Jerovec) & Quartz sand & 19.75 & - & $\begin{array}{c}\text { IGM Pješčara Jerovec d.o.o } \\
\text { Ivanec }\end{array}$ \\
\hline No. & Exploration area & Mineral raw material & Area / ha & JLS & Date of decision & Authorised person \\
\hline 1. & Jarek & Dolomite sand & 1.72 & Town Novi Marof [18] & $\begin{array}{c}\text { Constructor Vlado Puškadija, } \\
\text { Novi Marof }\end{array}$ \\
\hline
\end{tabular}

\subsection{Oil/Hydrocarbons}

According to the information provided by the Institute for Physical Planning of the Varaždin County, an oil exploration procedure was initiated in the territory of the Petrijanec municipality, and connected to this there is only a mark on the copy of the cadastral plan (cadastral municipality Družbinec) entered with a symbol and indicating the approximate location of the exploration well (Strmec Podravski I) [32].

Exploitation fields and exploration areas are defined in the spatial plans as the existing economic purpose - areas for exploration and exploitation of mineral resources, and the total area of this purpose in the spatial plans of the LSG is approximately 660.44 ha (existing stone exploitation fields 161.24 ha, clay 148.43 ha, gravel and sand 244.25 ha and quartz sand 19.21 ha, and planned spaces for the exploitation of stone 12.98 ha, clay 44.99 ha and gravel and sand 29.34 ha) [17].

It is extremely important that after the exploitation is completed or after a particular phase of exploitation, the area is rehabilitated and the final planned purpose of the area is realized.

Table 10 Hydrocarbons

\begin{tabular}{|c|c|c|c|c|c|}
\hline No. & Exploatation field & Mineral raw material & Area / ha & JLS & Authorised person \\
\hline 1. & Cvetkovec & Hydrocarbons & 423.00 & Town Ludbreg and Municipality Rasinja & INA - Industrija nafte d.d. Zagreb \\
\hline
\end{tabular}




\section{CONCLUSION}

The overall analysis and assessment of the situation in the management of mineral resources of the Varaždin County from 2006 to 2010, when the County Assembly adopted the Study of the potential and basis of mineral resources management in the Varaždin County in relation to the period when the new Mining Geological Study of Varaždin County was adopted (June, 2016), and according to the available data, which until 2017 were kept by the State Administration Offices (Economy Department), the Institute for Physical Planning of the Varaždin County and the Ministry of Economy, Directorate for Energy and Mining, and the applicable spatial planning documents. shows that the number of exploration areas and exploitation fields in the area of the Varaždin County for all mineral resources has increased.

Both Studies have analyzed the needs and potential of mineral resources through sustainable management of mineral resources both in economic and spatial planning field.

However, it is important to emphasize that the management of mineral resources of the Varaždin County (according to data from the current Mining and Geological Survey of the County of Varaždin, and related to data from the Ministry of Economy (MINGO), shows that the existing mineral reserves of construction sand and gravel, technical and construction stone are sufficient by 2045, and brick clay by 2053 . Consequently, there are currently sufficient quantities of mineral raw materials available for building materials for the construction of large infrastructure facilities and the manufacturing industry.

Through this analysis and assessment of the state of exploration and exploitation of mineral resources in the Varaždin County, all these years, there are certain problems, especially in relation to the environment (occupation of space, changes of landscapes, air pollution, water, impacts on flora, fauna, transport infrastructure) given the specificity of these activities. Namely, the exploitation of mineral resources inevitably means the degradation of space compared to its original state, since the image of space is permanently changing. Although areas are being rehabilitated after the cessation of mineral exploration activities (or planned to be rehabilitated according to a remediation project that is part of the documentation for the exploitation of the exploitation field), the possibilities of using the space after the exploitation are often limited, especially after the exploitation of gravel and sand (due to the presence of groundwater) and stone.

It is important to emphasize and conclude that the Varaždin County needs to determine the real possibilities for exploration and exploitation of mineral resources in accordance with the needs of the community and economic development, given that there are available quantities of mineral resources for the construction of larger infrastructure facilities. But it should also be emphasized that all relevant experts, miners, geologists, biologists, landscape architects should be actively involved in spatial planning in such a way as to identify potential sites of activation, so that decisions on the priorities for purpose, remediation or conservation can be made to ensure the protection of mineral deposits for future generations and to achieve development that promotes humane, sustainable, economical and environmentally friendly production.

\section{REFERENCES}

[1] Zakon o rudarstvu (NN 66/13, 14/14, 52/18, 115/18).

[2] Mesec, J., (2009). Mineralne sirovine, vrste $i$ načini dobivanja, Varaždin.

[3] Strategija prostornog razvoja Republike Hrvatske (NN 106/17).

[4] Marković, S. (2002): Hrvatske mineralne sirovine, institut za geološka istraživanja, Zavod za geologiju, Zagreb.

[5] Braun, K. at al. Engineering geological modelling. Croatin geological Congress, vol 125-131, Opatija.

[6] Strategija gospodarenja mineralni sirovina RH (2009. godina).

[7] Rudarsko - geološka studija Varaždinske županije ("Službeni vjesnik Varaždinske županije" br. 29/16)

[8] Zakon o zaštiti okoliša (NN 80/13, 153/13, 78/15, 12/18, 118/18)

[9] Zakonu o vodama (NN 153/09, 63/11, 130/11, 56/13, $14 / 14)$

[10] Zakon o prostornom uređenju (NN 153/13, 65/17, 114/18, 39/19).

[11] Pravilniku o sadržaju, mjerilima kartografskih prikaza, obveznim prostornim pokazateljima i standardu elaborata prostornih planova (NN 106/98, 39/04, 45/04, 163/04, 148/10).

[12] Prostorni plan Varaždinske županije ("Službeni vjesnik Varaždinske županije" 8/00, 29/06, 16/09).

[13] Studija potencijala i osnove gospodarenja mineralni sirovinama na području Varaždinske županije ("Službenom vjesniku Varaždinske županije" 9/08).

[14] Izvješće o stanju okoliša za razdoblje 2010. - 2013. god. (Zaključak o prihvaćanju Izvješća "Službeni vjesnik Varaždinske županije" 29/14)

[15] Kovačić, M. \& Pekaš. Ž. (2003). Gospodarenje hrvatskim geotermalnim vodama sukladno koncepciji održivog razvoja - cijevi i usmjerenja. Zbornik radova 3. Hrvatske konferencije o vodama, Osijek.

[16] Zakon o zaštiti prirode (NN 80/13, 15/18, 14/19).

[17] Izvješće o stanju u prostoru Varaždinske županije za razdoblje 2010. - 2015. god. ("Službeni vjesnik Varaždinske županije" .9/16)

[18] Prostorni plan uređenja Grada Novog Marofa ("Službeni vjesnik Varaždinske županije" .16/02, 55/09).

[19] Prostorni plan uređenja Općine Visoko ("Službeni vjesnik Varaždinske županije" 10/03, 15/07, 42/10).

[20] Nakić. Z. (2010). Geologija okoliša, Zagreb.

[21] Prostorni plan uređenja Grada Ivanca ("Službeni vjesnik Varaždinske županije" 6/01, 2/08, 24/12, 32/14, 43/14 pročišćeni tekst).

[22] Prostorni plan uređenja Grada Lepoglave ("Službeni vjesnik Varaždinske županije" 16/03, 27/07, 16A/14).

[23] Prostorni plan uređenja Grada Ludbrega ("Službeni vjesnik Varaždinske županije" 6/03, 22/08, 7/10,6/15, 25/15 pročišćeni tekst).

[24] Prostorni plan uređenja Grada Varaždinske Toplice ("Službeni vjesnik Varaždinske županije" 9/05, 5/09, 5/10, 12/15).

[25] Prostorni plan uređenja Općine Breznički Hum ("Službeni vjesnik Varaždinske županije" 5/02, 55/12, 46/14).

[26] Prostorni plan uređenja Općine Cestica ("Službeni vjesnik Varaždinske županije" 10/04, 29/05, 23/06, 31/06, 5/07, 29/07, 1/13)

[27] Prostorni plan uređenja Općine Gornji Kneginec ("Službeni vjesnik Varaždinske županije"12/01, 18/03, 30/03, 2/04, 
24/06 and "Službeni vjesnik Općine Gornji Kneginec" $7 / 13)$

[28] Prostorni plan uređenja Općine Ljubešćica ("Službeni vjesnik Varaždinske županije" 03/04, 39/10, 25/12).

[29] Prostorni plan uređenja Općine Mali Bukovec ("Službeni vjesnik Varaždinske županije" 8/05).

[30] Prostorni plan uređenja Općine Martijanec ("Službeni vjesnik Varaždinske županije" 19/03, 02/13).

[31] Prostorni plan uređenja Općine Maruševec ("Službeni vjesnik Varaždinske županije" 23/02, 27/06, 22/13).

[32] Prostorni plan uređenja Općine Petrijanec ("Službeni vjesnik Varaždinske županije" 18/07, 41/12).

[33] Prostorni plan uređenja Općine Sračinec ("Službeni vjesnik Varaždinske županije" 29/02, 29/05, 7/12).

[34] Prostorni plan uređenja Općine Sveti Đurđ ("Službeni vjesnik Varaždinske županije" br. 16/04, 25/04, 27/07, 41/07, 20/11, 81/13).

[35] Prostorni plan uređenja Općine Trnovec Bartolovečki ("Službeni vjesnik Varaždinske županije" 22/00, 03/02, 06/05, 28/12).

\section{Contact information:}

Melita SRPAK, univ. spec. oec., mag. agr.

(Corresponding author)

Varaždin County, Institute for Physical Planning,

Mali Plac 1a, 42000 Varaždin, Croatia

E-mail: melita.srpak@gmail.com

Silvija ZEMAN, PhD

Polytechnic of Međimurje in Čakovec,

Bana Josipa Jelačića 22a, 40000 Čakovec, Croatia

E-mail: silvija.zeman@mev.hr

Željko KNOK, Mag. Ing.

Polytechnic of Međimurje in Čakovec,

Bana Josipa Jelačića 22a, 40000 Čakovec, Croatia

E-mail:z.knok@mev.hr 